\title{
Pregnancy, Labor, and Delivery after Ebola Virus Disease and Implications for Infection Control in Obstetric Services, United States
}

Amanda Kamali, Denise J. Jamieson, Julius Kpaduwa, Sarah Schrier, Moon Kim, Nicole M. Green, Ute Ströher, Atis Muehlenbachs, Michael Bell, Pierre E. Rollin, Laurene Mascola

\begin{abstract}
Medscape ACTIVITY
Medscape, LLC is pleased to provide online continuing medical education (CME) for this journal article, allowing clinicians the opportunity to earn CME credit.

This activity has been planned and implemented in accordance with the Essential Areas and policies of the Accreditation Council for Continuing Medical Education through the joint providership of Medscape, LLC and Emerging Infectious Diseases. Medscape, LLC is accredited by the ACCME to provide continuing medical education for physicians.

Medscape, LLC designates this Journal-based CME activity for a maximum of 1.0 AMA PRA Category 1 Credit(s) ${ }^{T M}$. Physicians should claim only the credit commensurate with the extent of their participation in the activity.

All other clinicians completing this activity will be issued a certificate of participation. To participate in this journal CME activity: (1) review the learning objectives and author disclosures; (2) study the education content; (3) take the post-test with a $75 \%$ minimum passing score and complete the evaluation at http://www.medscape.org/journal/eid; (4) view/print certificate.
\end{abstract}

Release date: May 19, 2016; Expiration date: May 19, 2017

Learning Objectives

Upon completion of this activity, participants will be able to:

- Assess the potential for Ebola virus to complicate pregnancy

- Analyze obstetric interventions and outcomes of a case of a pregnant woman with a history of Ebola virus diseases (EVD)

- Evaluate precautions taken during labor and delivery involving this patient with a history of EVD

- Distinguish laboratory testing results for Ebola virus among the mother and infant in the current case.

\section{CME Editor}

Claudia Chesley, Technical Writer/Editor, Emerging Infectious Diseases. Disclosure: Claudia Chesley has disclosed no relevant financial relationships.

\section{CME Author}

Charles P. Vega, MD, Clinical Professor of Family Medicine, University of California, Irvine. Disclosure: Charles $P$. Vega, MD, has disclosed the following financial relationships: served as an advisor or consultant for Allergan, Inc.; McNeil Consumer Healthcare; served as a speaker or a member of a speakers bureau for Shire Pharmaceuticals.

\section{Authors}

Disclosures: Amanda Kamali, MD, has disclosed the following relevant financial relationships: owns stock, stock options, or bonds from Pfizer. Denise J. Jamieson, MD, MPH; Julius Kpaduwa, MD; Sarah Schrier, RNC-OB, MSN; Moon Kim, MD, MPH; Nicole M. Green, PhD; Ute Ströher; Atis Muehlenbachs, MD, PhD; Michael Bell, MD; and Pierre E. Rollin, MD, have disclosed no relevant financial relationships. Laurene Mascola, MD, MPH, has disclosed the following relevant financial relationships: served as a speaker or a member of a speakers bureau for Merck.

Author affiliations: Centers for Disease Control and Prevention, Atlanta, Georgia, USA (A. Kamali, D.J. Jamieson, U. Ströher, A. Muehlenbachs, M. Bell, P.E. Rollin); Los Angeles County Department of Public Health, Los Angeles, California, USA
(A. Kamali, M. Kim, N.M. Green, L. Mascola); Greater El Monte Community Hospital, South El Monte, California, USA

(J. Kpaduwa, S. Schrier)

DOI: http://dx.doi.org/10.3201/eid2207.160269 
Many of the survivors of the 2014-2015 epidemic of Ebola virus disease (EVD) in West Africa were women of childbearing age. Limited clinical and laboratory data exist that describe these women's pregnancies and outcomes. We report the case of an EVD survivor who became pregnant and delivered her child in the United States, and we discuss implications of this case for infection control practices in obstetric services. Hospitals in the United States must be prepared to care for EVD survivors.

$\mathrm{T}$ he 2014-2015 epidemic of Ebola virus disease (EVD), which was centered in West Africa, is the largest EVD epidemic in history. Vertical transmission of Ebola virus from mother to fetus can occur during acute Ebola infection, leading to intrauterine fetal death, stillbirth, or neonatal death $(1-5)$. Little is known about the risk for vertical transmission of Ebola virus from women to their neonates outside of the acute infectious period. Ebola virus (EBOV) has been found in breast milk during acute disease (O), and a study documenting 2 discordant mother-child pairs postulated that breast feeding of 1 infant may have led to infection of the infant (7). EBOV has been found in immune-privileged sites, ocular fluid and semen, many months after onset of infection $(8-13)$, and it is possible that other immune-privileged sites, such as the central nervous system (CNS), may also contain EBOV many months after onset of infection. In addition, acutely infected pregnant women have had high amounts of Ebola viral nucleic acid persist in the amniotic fluid following clearance of viremia; however, it is not known whether this amniotic fluid is infectious (2). Some theoretical concern exists that during labor and delivery or obstetric anesthetic procedures (e.g., spinal anesthesia), contact with products of conception or cerebrospinal fluid from EVD survivors may pose an infectious risk $(6,14-18)$.

As of March 9, 2016, an estimated 17,323 persons worldwide have survived EVD, and among them are $\approx 5,000$ women of childbearing age (19). Survivors will require medical care for routine illnesses, surgical services, dental work, and management of disease sequelae $(20,21)$. In addition, many of the female survivors who are of reproductive age will require obstetric care. Some of these survivors may come to the United States, and hospitals and healthcare workers must be prepared to provide care in a manner that promotes patient dignity and comfort, prevents stigmatization, and ensures that all patients receive appropriate, high-quality medical care (22-24). However, limited preparations have been made for follow-up care for EVD survivors, including those needing obstetric care. We describe the case of an EVD survivor who delivered a healthy neonate in a community hospital in the United States 14 months after acute EBOV infection, and we discuss the implications of the findings from this case for infection control in obstetric services.

\section{Clinical Course}

\section{Ebola Virus Disease Course}

A 29-year-old physician from West Africa became ill with EVD in late July 2014. She had contracted the virus from an EVD patient whom she had cared for from July 20 th until his death on July 25 . On July 29 , the woman began feeling unwell, noting arthralgia and myalgia, which she self-treated with antimalarial medications. On August 1, she had fever, and on August 3, she began vomiting and had diarrhea. The woman was admitted to an Ebola treatment center (ETC) and isolated after results of an EBOV real-time reverse transcription PCR (rRT-PCR) were positive for EBOV RNA (cycle threshold unknown). According to the woman, she spent 13 days in the ETC, where she was treated with oral rehydration fluids, acetaminophen, and a second course of antimalarial medications. She was discharged from the ETC on August 16, after showing negative results on 2 EBOV rRT-PCRs. After her recovery, the woman noted some fatigue, anorexia, arthralgia, and alopecia; she did not report any sleep disturbances, headaches, or vision problems. Symptoms resolved 2-3 months later.

\section{Pregnancy, Labor, and Delivery}

Eight months before her EVD diagnosis, the patient had had a spontaneous abortion at 10 weeks' gestation. In January 2015, twenty-two weeks after her last negative EBOV rRT-PCR, she became pregnant again. For this second pregnancy, the estimated date of delivery was established on the basis of an 11.5-week ultrasound that was consistent with the patient's last menstrual period. The patient received routine prenatal care in West Africa, and at 25 weeks' gestation, she traveled to Kern County, California, USA, and a detailed anatomy ultrasound was performed in Los Angeles County, California, and demonstrated normal fetal development.

The hospital identified staff members who were willing to assist during labor and delivery for the patient, and at 40 weeks and 1 day of gestation, labor was induced to ensure that those staff members were present. The patient was given 2 vaginal doses of misoprostol, and oxytocin was administered, and labor progressed normally. The patient was given epidural anesthesia for pain control and had a normal vaginal delivery of a female neonate (weight $4,128 \mathrm{~g}$ ) with Apgar scores of 8 and 9 at 1 and 5 min of age, respectively. The patient had a second-degree perineal laceration, which was repaired.

The patient and her neonate were discharged from the hospital at $36 \mathrm{~h}$ postpartum. They returned for routine follow-up 7 days postpartum and were monitored for 6 weeks following delivery, after which they traveled home to West Africa. 


\section{Infection Control and Personal Protective Equipment, Public Health Response}

Two weeks before the patient's delivery date, her US obstetrician contacted the California Department of Public Health (DPH; Richmond, CA, USA) and the Centers for Disease Control and Prevention (CDC; Atlanta, GA, USA) to determine if there were any special precautions needed for infection control; the California DPH notified the Los Angeles County DPH (Los Angeles, CA, USA). Because the patient was healthy and had fully recovered from $E V D \approx 4$ months before becoming pregnant, all public health agencies agreed that she presented an extremely low risk for transmission of Ebola virus. Nevertheless, it was deemed appropriate that public health officials play an active role assessing and guiding management of the patient. The Los Angeles County DPH and CDC collaborated with the hospitals healthcare providers, nursing directors, laboratory director, environmental services staff, anesthesiologists, and hospital administration to address concerns and review the care plan, including plans for any complications, such as the need for cesarean delivery or the development of peripartum fever.

Hospital infection control procedures were reviewed in person with hospital staff. In review of these policies, no additional precautions were recommended above the standard precautions and policies currently used for all deliveries at the hospital. Several hospital staff members not directly involved in patient care expressed discomfort about working while an EVD survivor was admitted. To reassure these staff members, the patient was kept in 1 room during labor and delivery and after delivery. No changes were made to the policies for environmental cleaning or waste disposal.

Hospital staff raised concerns about the possibility of EBOV being harbored in immune-privileged sites (e.g., cerebrospinal fluid) in EVD survivors and, thus, expressed their concerns about a theoretical risk for EBOV transmission $(6,14-17)$. This patient did not show signs or symptoms of CNS involvement during her acute illness or during her pregnancy, which likely indicated a decreased risk of any latent EBOV reservoir in her CNS; thus, it was considered likely that epidural or spinal anesthesia for this patient would not pose an infectious risk to staff. Hospital staff also noted the often imperfect adherence to use of personal protective equipment (PPE) during labor and delivery; thus, they voiced concern over this patient's history of EVD because large volumes of blood and amniotic fluid are often encountered in typical, uncomplicated vaginal deliveries (25). As a result of these concerns, many discussions were held regarding what PPE should be used during labor and delivery. Standard precautions should always be applied in all medical settings, including labor and delivery; however, neither CDC nor the American College of Obstetricians and Gynecologists had tailored recommendations for PPE specifically for vaginal or cesarean deliveries for any patients. Thus, CDC and Los Angeles County DPH developed a preliminary set of recommendations for the patient's providers regarding the use of PPE (Tables 1,2) during and after labor and delivery to ensure that standard precautions were implemented. These PPE recommendations were discussed with the providers in the days before the delivery, and staff members were able to ask for clarification and ensure that materials were readily available. These PPE recommendations did not differ from standard precautions, but they explicitly discussed which PPE to use for casual contact, vaginal examinations, labor and delivery, anesthesia, and postpartum care. Routine hand hygiene, the use of barriers for mucous membrane protection, and the use of double gloves for procedures that involve sharps were emphasized.

Table 1. Recommendations for use of personal protective equipment by healthcare workers during labor and delivery for a woman who became pregnant after surviving Ebola virus disease, United States, 2015*

\begin{tabular}{|c|c|c|c|c|c|c|c|}
\hline \multirow[b]{4}{*}{ Potential exposure } & \multicolumn{7}{|c|}{ Personal protective equipment } \\
\hline & \multirow{3}{*}{$\begin{array}{l}\text { Face } \\
\text { mask }\end{array}$} & \multirow{3}{*}{$\begin{array}{l}\text { Face } \\
\text { shield }\end{array}$} & \multicolumn{2}{|r|}{ Gown } & \multirow{2}{*}{\multicolumn{2}{|c|}{ Gloves }} & \multirow{3}{*}{$\begin{array}{c}\text { Fluid-resistant, } \\
\text { midcalf boot } \\
\text { covers }\end{array}$} \\
\hline & & & \multirow[b]{2}{*}{ Isolation } & \multirow{2}{*}{$\begin{array}{l}\text { Fluid-resistant or } \\
\text { impermeable† }\end{array}$} & & & \\
\hline & & & & & Single & Double & \\
\hline \multicolumn{8}{|l|}{ Casual contact with patient } \\
\hline $\begin{array}{l}\text { Performing duties for patient with intact } \\
\text { membranes (e.g., delivering food or water, } \\
\text { talking with patient, adjusting external monitors) }\end{array}$ & No & No & No & No & No & No & No \\
\hline $\begin{array}{l}\text { Performing duties for patient with ruptured } \\
\text { membranes; no touching of patient or bedding }\end{array}$ & No & No & No & No & No & No & No \\
\hline \multicolumn{8}{|l|}{ Noncasual contact with patient } \\
\hline $\begin{array}{l}\text { Touching patient with ruptured membranes or } \\
\text { bedding of patient with ruptured membranes }\end{array}$ & No & No & Yes & No & Yes & No & No \\
\hline Administering epidural & Yes & Yes & Yes & No & No & Yes & Yesł \\
\hline Performing vaginal examination & Yes & Yes & No & Yes & Yes & No & Yesł \\
\hline Performing obstetric procedures§ & Yes & Yes & No & Yes & Yes & Yes & Yes \\
\hline
\end{tabular}

*These personal protective equipment recommendations were developed for this particular patient and do not represent a formal recommendation. tImpermeable indicates that the material and construction have demonstrated resistance to synthetic blood and simulated bloodborne pathogens; fluidresistant indicates demonstrated resistance to water (http://www.cdc.gov/niosh/nppt//topics/protectiveclothing/default.html).

$\ddagger$ To be used if membranes were ruptured.

§Procedures include placement of fetal scalp electrode or intrauterine pressure catheter; manual removal of placenta; bimanual massage of uterine. 
EVD and Infection Control in Obstetric Services

Table 2. Recommendations for use of personal protective equipment by healthcare workers during postpartum care of a woman who became pregnant after surviving Ebola virus disease and during care of her neonate, United States, 2015*

\begin{tabular}{|c|c|c|c|c|c|c|c|}
\hline \multirow[b]{2}{*}{ Level of care } & \multirow[b]{2}{*}{ Face mask } & \multirow[b]{2}{*}{ Face shield } & \multicolumn{2}{|r|}{ Gown } & \multicolumn{2}{|c|}{ Gloves } & \multirow{2}{*}{$\begin{array}{l}\text { Fluid-resistant } \\
\text { midcalf boot } \\
\text { covers }\end{array}$} \\
\hline & & & Isolation & $\begin{array}{l}\text { Fluid-resistant or } \\
\text { impermeable } \dagger\end{array}$ & Single & Double & \\
\hline \multicolumn{8}{|l|}{ While caring for mother } \\
\hline Before bedding/gown change & Yes & Yes & No & Yes & Yes & No & Yes \\
\hline $\begin{array}{l}\text { After bedding/gown change } \\
\text { (vaginal exam, perineal care) }\end{array}$ & $\begin{array}{l}\text { No, unless } \\
\text { splash likely }\end{array}$ & $\begin{array}{l}\text { No, unless } \\
\text { splash likely }\end{array}$ & Yes & No & Yes & No & No \\
\hline \multicolumn{8}{|l|}{ While caring for neonate } \\
\hline Before bathing & Yes & Yes & No & Yes & Yes & No & Yes \\
\hline After bathing & No & No & No & No & Yesł & No & No \\
\hline \multicolumn{8}{|c|}{$\begin{array}{l}{ }^{*} \text { These personal protective equipment recommendations were developed for this particular patient and do not represent a formal recommendation. } \\
\text { †Impermeable indicates that the material and construction have demonstrated resistance to synthetic blood and simulated bloodborne pathogens; fluid- } \\
\text { resistant indicates demonstrated resistance to water (http://www.cdc.gov/niosh/nppt/topics/protectiveclothing/default.html). } \\
\ddagger \text { To be used if exposure to fluids is likely. }\end{array}$} \\
\hline
\end{tabular}

\section{Laboratory Assessment}

One week before delivery, EBOV rRT-PCR testing was performed on the patient's blood by the Los Angeles County DPH laboratory and the CDC Viral Special Pathogens Branch; both results were negative. As expected, Ebola serum antibodies were detected by ELISA ( $\operatorname{IgG} \geq 1: 1600$, IgM negative).

After obtaining written informed consent from the patient, healthcare staff obtained the following during and after delivery: vaginal secretions, amniotic fluid (vaginal pool), cord blood, placenta, umbilical cord, breast milk (colostrum collected $16 \mathrm{~h}$ after delivery), and oral and ear swab samples from the neonate. Cord blood, colostrum, amniotic fluid, and swab samples were kept refrigerated until processed or frozen on dry ice for shipment to CDC. A placental sample was frozen in a sterile specimen cup and samples of placenta and umbilical cord were placed in buffered formalin and shipped at room temperature to CDC. EBOV rRT-PCR testing was performed on all of these specimens at the Los Angeles County DPH and CDC laboratories by using assays specific for nucleoprotein and viral protein 40 genes.

Placenta, amniotic fluid, and cord blood samples and ear and oral swab samples from the neonate were negative by EBOV rRT-PCR. Attempts were made to recover virus from placenta, amniotic fluid, cord blood, and colostrum at $\mathrm{CDC}$, but no virus was recovered (Table 3). Amniotic fluid, cord blood, and colostrum were tested by ELISA for IgM and IgG against Ebola virus antigens (26). Cord blood was negative for $\operatorname{IgM}$ and had an $\operatorname{IgG}$ titer of $\geq 1: 1600$. Amniotic fluid and colostrum were negative for $\operatorname{IgM}$ and IgG. The placenta and umbilical cord were histologically normal, and no Ebola virus antigen was detected by immunohistochemistry (27), including in maternal and fetal endothelial cells and leukocytes.

\section{Conclusions}

We describe the delivery of a healthy baby to an EVD survivor who became pregnant 22 weeks after clearance of viremia and resolution of post-EVD sequelae (i.e., fatigue, anorexia, arthralgia). At 6 weeks follow-up, before returning to West Africa, the mother and baby were doing well. Given that the mother did not exhibit any signs or symptoms of post-EVD sequelae during her pregnancy, we did not expect to find any EBOV by rRT-PCR in any specimens obtained, and none was detected. It is somewhat surprising that we did not detect Ebola IgG in the colostrum; however, studies of antibodies for other infections have found that levels of IgG and IgM in colostrum are much lower than in serum (28), and this might also be true for antibodies against EBOV.

Although we did not detect EBOV RNA in this patient during pregnancy, women who are pregnant during acute EBOV infection usually transmit virus to the fetus and may pose an infectious risk to healthcare providers and others during delivery or abortion (3). EBOV can readily cross the placenta, and pathologic examination of placental tissues of patients with confirmed EVD have demonstrated EBOV antigen in the trophoblasts, syncytiotrophoblasts, and circulating maternal macrophages (4). EBOV RNA has been demonstrated in amniotic fluid; fetal meconium; vaginal secretions; umbilical cord; buccal swab samples from neonates; and peripheral blood samples from neonates, including those of mothers with cleared viremia $(29,30)$.

The immune effects of pregnancy in the context of EVD have not been well documented (3); however, alterations in the immune system do occur during pregnancy (31), which during acute EBOV infection likely increases the risk for a poor outcome, including spontaneous abortion and neonatal death. Unlike the CNS, eye, and male testis, the genital tract of a nongravid female is not traditionally considered an immune-privileged site (32-34). Laboratory data that demonstrate the absence of EBOV or the presence of antibodies in post-EVD pregnancies are lacking; however, on the basis of epidemiological evidence in the field of multiple uneventful deliveries in West Africa and of the laboratory-analyzed case reported here, no evidence currently exists that Ebola virus can persist in the female genital tract. Any perceived risk must be mitigated to ensure that patients are not stigmatized and 
Table 3. Laboratory test results for a woman who became pregnant after surviving Ebola virus disease and for her neonate, United States, 2015*

\begin{tabular}{lcccc}
\hline Source & Time of sample collection & rRT-PCR & Ebola antibodies & Immunohistochemistry \\
\hline Maternal blood & 1 week before delivery & Negative & IgG $(1: 1,600) ;$ IgM not detected & NA \\
Cord blood & At delivery & Negative & IgG $(1: 1,600) ;$ IgM not detected & NA \\
Amniotic fluid & At delivery & Negative & IgG; IgM not detected & NA \\
Vaginal swab sample & At delivery & Negative & NA & NA \\
Neonate ear swab sample & At delivery & Negative & NA & NA \\
Neonate oral swab sample & At delivery & Negative & NA & NA \\
Placenta & At delivery & Negative & NA & Negative for Ebola antigen \\
Umbilical cord & At delivery & NA & IgG and IgM not detected & NA \\
Colostrum & 1 day after delivery & Negative & antigen \\
\hline *NA, not applicable; rRT-PCR, real-time reverse transcription PCR. & & & \\
\hline
\end{tabular}

receive appropriate care. The authors concur with current guidelines by the World Health Organization, which state that women who have recovered from EVD are not infectious and should receive routine prenatal care, and their labor and delivery should be performed using standard PPE for protection against blood and body fluids (35).

The normal pregnancy for the patient described in this study and her delivery of a healthy neonate offer reassurance that women who become pregnant after recovery from EVD pose little risk for transmission of EBOV to the baby or others. Many more EVD survivors will become pregnant and deliver, and some may do so in the United States. Many other survivors will require routine medical care, including care for post-EVD syndrome. Lessons learned from this patient, specifically those addressing concerns about potential risks for virus transmission, may be applied to future patients. However, each survivor who seeks medical care will likely need to be assessed individually to determine possible risks for transmitting virus $(16,18)$. Over the course of the public health involvement in this case, it became evident that, although standard precautions should routinely be used in all labor and delivery settings, written guidelines for labor and delivery may be useful, given the heightened concern for a theoretical disease transmission risk. We hope that the preliminary recommendations for PPE use during labor and delivery in the case discussed here will provide a template for other professional organizations to create guidelines for use in all labor and delivery settings.

\section{Acknowledgments}

We thank Cheryl Starling, Benjamin Schwartz, and Claudia Jonah for assistance in coordinating care for the patient; Clara Tyson, Geri Braddock, Juliet Bugante, Elizabeth Traub, and Dawn Terashita for assistance in ensuring appropriate hospital infection control procedures were in place; Viviana Torres, Nicholas Miranda, Robert Tran, Julio Ramirez, Carlos Garcia, Sascha Ellington, Aridth Gibbons, Shelley Brown, and Ketan Patel for performing laboratory testing; Stanley Toy for administrative leadership; Stella Kpaduwa for clinical care of the neonate; and Inger Damon, Dana Meaney-Delman, Oliver Morgan, Maleeka Glover, Timothy Uyeki, and Jana M. Ritter for guidance and assistance with personal protective equipment recommendations.

Dr. Kamali, an Epidemic Intelligence Service Officer in the Center for Surveillance, Epidemiology and Laboratory Services, Centers for Disease Control and Prevention, is based at the Los Angeles County Department of Public Health as a physician specializing in infectious diseases. Her interests include emerging infectious diseases, antimicrobial resistance, and stewardship.

\section{References}

1. Akerlund E, Prescott J, Tampellini L. Shedding of Ebola virus in an asymptomatic pregnant woman. N Engl J Med. 2015;372:2467-9. http://dx.doi.org/10.1056/NEJMc1503275

2. Baggi FM, Taybi A, Kurth A, Van Herp M, Di Caro A, Wolfel R, et al. Management of pregnant women infected with Ebola virus in a treatment centre in Guinea, June 2014. Euro Surveill. 2014;19:20983. http://dx.doi.org/10.2807/1560-7917. ES2014.19.49.20983

3. Black BO, Caluwaerts S, Achar J. Ebola viral disease and pregnancy. Obstet Med. 2015;8:108-13. http://dx.doi.org/10.1177/ $1753495 X 15597354$

4. Muehlenbachs A, de la Rosa Vazquez O, Bausch DG, Schafer IJ, Paddock CD, Bergeron E, et al. Ebola virus disease in pregnancy: histopathologic and immunohistochemical findings. Presented at: Abstracts of the American Society of Tropical Medicine and Hygiene 64th Annual Meeting; 2015 Oct 25-29; Philadelphia, PA, USA. Abstract LB-5108.

5. Mupapa K, Mukundu W, Bwaka MA, Kipasa M, De Roo A, Kuvula K, et al. Ebola hemorrhagic fever and pregnancy. J Infect Dis. 1999;179(Suppl 1):S11-2. http://dx.doi.org/10.1086/514289

6. Bausch DG, Towner JS, Dowell SF, Kaducu F, Lukwiya M, Sanchez A, et al. Assessment of the risk of Ebola virus transmission from bodily fluids and fomites. J Infect Dis. 2007;196(Suppl 2):S142-7. http://dx.doi.org/10.1086/520545

7. Moreau M, Spencer C, Gozalbes JG, Colebunders R, Lefevre A, Gryseels S, et al. Lactating mothers infected with Ebola virus: EBOV RT-PCR of blood only may be insufficient. Euro Surveill. 2015;20:21017. http://dx.doi.org/10.2807/ 1560-7917.ES2015.20.3.21017

8. Deen GF, Knust B, Broutet N, Sesay FR, Formenty P, Ross C, et al. Ebola RNA persistence in semen of Ebola virus disease survivors - preliminary report. N Engl J Med. Epub 2015 Oct 14.

9. Mate SE, Kugelman JR, Nyenswah TG, Ladner JT, Wiley MR, Cordier-Lassalle T, et al. Molecular evidence of sexual transmission of Ebola virus. N Engl J Med. 2015. Epub 2015 Oct 14. 
10. Varkey JB, Shantha JG, Crozier I, Kraft CS, Lyon GM, Mehta AK, et al. Persistence of Ebola virus in ocular fluid during convalescence. N Engl J Med. 2015;372:2423-7. http://dx.doi.org/ 10.1056/NEJMoa1500306

11. Fischer WA II, Wohl DA. Confronting Ebola as a sexually transmitted infection. Clin Infect Dis. Epub 2016 Mar 1.

12. Howlett P, Brown C, Helderman T, Brooks T, Lisk D, Deen G, et al. Ebola virus disease complicated by late-onset encephalitis and polyarthritis, Sierra Leone. Emerg Infect Dis. 2016;22:150-2. http://dx.doi.org/10.3201/eid2201.151212

13. Rowe AK, Bertolli J, Khan AS, Mukunu R, Muyembe-Tamfum JJ, Bressler D, et al. Clinical, virologic, and immunologic follow-up of convalescent Ebola hemorrhagic fever patients and their household contacts, Kikwit, Democratic Republic of the Congo. Commission de Lutte contre les Epidémies à Kikwit. J Infect Dis. 1999;179(Suppl 1):S28-35. http://dx.doi.org/10.1086/ 514318

14. Barkhordarian A, Thames AD, Du AM, Jan AL, Nahcivan M, Nguyen MT, et al. Viral immune surveillance: toward a TH17/TH9 gate to the central nervous system. Bioinformation. 2015;11:47-54. http://dx.doi.org/10.6026/97320630011047

15. Brainard J, Pond K, Hooper L, Edmunds K, Hunter P. Presence and persistence of Ebola or Marburg virus in patients and survivors: a rapid systematic review. PLoS Negl Trop Dis. 2016;10:e0004475. http://dx.doi.org/10.1371/journal.pntd.0004475

16. Sonnenberg P, Field N. Sexual and mother-to-child transmission of Ebola virus in the postconvalescent period. Clin Infect Dis. 2015;60:974-5. http://dx.doi.org/10.1093/cid/ciu981

17. Farge E, Giahyue JH. Female survivor may be cause of Ebola flare-up in Liberia. Reuters. 2015 Dec 17. In: Kaye D. 15 March news. Clin Infect Dis. 2016;62:i-ii. http://dx.doi.org/10.1093/cid/civ1211

18. Centers for Disease Control and Prevention. Interim guidance for management of survivors of Ebola virus disease in US healthcare settings. 2016 [cited 2016 Mar 18]. http://www.cdc.gov/vhf/ebola/ healthcare-us/evaluating-patients/guidance-for-management-ofsurvivors-ebola.html

19. World Health Organization. Ebola data and statistics: situation summary 09, March 2016. 2016 Mar 11 [cited 2016 Mar 18]. http://apps.who.int/gho/data/view.ebola-sitrep.ebola-summary20160309?lang=en

20. Bausch DG. Sequelae after Ebola virus disease: even when it's over it's not over. Lancet Infect Dis. 2015;15:865-6. http://dx.doi.org/ 10.1016/S1473-3099(15)70165-9

21. Clark DV, Kibuuka H, Millard M, Wakabi S, Lukwago L, Taylor A, et al. Long-term sequelae after Ebola virus disease in Bundibugyo, Uganda: a retrospective cohort study. Lancet Infect Dis. 2015;15:905-12. http://dx.doi.org/10.1016/ S1473-3099(15)70152-0

22 Kupferschmidt K. Infectious diseases. Surviving Ebola survival. Science. 2015;348:1406-7. http://dx.doi.org/10.1126/ science.348.6242.1406
23. Minkoff H, Ecker J. Physicians' obligations to patients infected with Ebola: echoes of acquired immune deficiency syndrome. Am J Obstet Gynecol. 2015:212;456.e1-4.

24. Sprecher A. Handle survivors with care. N Engl J Med. Epub 2015 Oct 14.

25. Magann EF, Bass JD, Chauhan SP, Young RA, Whitworth NS, Morrison JC. Amniotic fluid volume in normal singleton pregnancies. Obstet Gynecol. 1997;90:524-8. http://dx.doi.org/ 10.1016/S0029-7844(97)00351-7

26. Ksiazek TG, West CP, Rollin PE, Jahrling PB, Peters CJ. ELISA for the detection of antibodies to Ebola viruses. J Infect Dis. 1999;179(Suppl 1):S192-8. http://dx.doi.org/10.1086/514313

27. Martines RB, Ng DL, Greer PW, Rollin PE, Zaki SR. Tissue and cellular tropism, pathology and pathogenesis of Ebola and Marburg viruses. J Pathol. 2015;235:153-74. http://dx.doi.org/10.1002/ path.4456

28. Wheeler TT, Hodgkinson AJ, Prosser CG, Davis SR. Immune components of colostrum and milk-a historical perspective. J Mammary Gland Biol Neoplasia. 2007;12:237-47.

29. Bower H, Grass JE, Veltus E, Brault A, Campbell S, Basile AJ, et al. Delivery of an Ebola virus-positive stillborn infant in a rural community health center, Sierra Leone, January 2015. Am J Trop Med Hyg. 2016;94:417-9. http://dx.doi.org/10.4269/ ajtmh.15-0619

30. Oduyebo T, Pineda D, Lamin M, Leung A, Corbett C, Jamieson DJ. A pregnant patient with Ebola virus disease. Obstet Gynecol. 2015;126:1273-5. http://dx.doi.org/10.1097/ AOG.0000000000001092

31. Kourtis AP, Read JS, Jamieson DJ. Pregnancy and infection. N Engl J Med. 2014;371:1077.

32. Clark GF, Schust DJ. Manifestations of immune tolerance in the human female reproductive tract. Front Immunol. 2013;4:26. http://dx.doi.org/10.3389/fimmu.2013.00026

33. Mital P, Hinton BT, Dufour JM. The blood-testis and bloodepididymis barriers are more than just their tight junctions. Biol Reprod. 2011;84:851-8. http://dx.doi.org/10.1095/ biolreprod.110.087452

34. Muldoon LL, Alvarez JI, Begley DJ, Boado RJ, Del Zoppo GJ, Doolittle ND, et al. Immunologic privilege in the central nervous system and the blood-brain barrier. J Cereb Blood Flow Metab. 2013;33:13-21. http://dx.doi.org/10.1038/jcbfm.2012.153

35. World Health Organization. Interim guidance: Ebola virus disease in pregnancy: screening and management of Ebola cases, contacts and survivors. 2015 Sep 4 [cited 2015 Nov 11]. http://apps.who.int/ iris/bitstream/10665/184163/1/WHO_EVD_HSE_PED_15.1_eng. pdf?ua $=1$

\title{
Medscape Sign up to receive email announcements when a new article is available.
}

\author{
Get an online subscription at wwwnc.cdc.gov/eid/subscribe.htm
}

